


\title{
Design of Novel Benzimidazole Derivatives as Potential a-amylase Inhibitors by 3D-QSAR Modeling and Molecular Docking Studies
}

\author{
Khalil El Khatabi $\triangle(D)$ Ilham Aanouz $\triangle D$, Reda El-Mernissi $\triangle D$, Ayoub Khaldan $\triangle D$, \\ Mohammed Aziz Ajana* $\triangle D$, Mohammed Bouachrine $\triangle D$, Tahar Lakhlifi $\triangle$ D
}

University of Moulay Ismail, Faculty of Science, MCNSL, Meknes, Morocco.

\begin{abstract}
The enzyme a-amylase belongs to the highly conserved glycoside hydrolase family which is regarded as a good target for the discovery of antidiabetic agents. Following a 3D-QSAR study on forty-five 2-aryl benzimidazole derivatives which have been reported as potential insulin-independent antidiabetic agents. The results revealed that the CoMFA values were found to be 0.696 and 0.860 for $Q^{2}$ and $R^{2}$ respectively; while for the CoMSIA, the $\mathrm{Q}^{2}$ and $\mathrm{R}^{2}$ values were found to be 0.514 and 0.852 respectively. Both models were derived from a training set of thirty-seven compounds based on an appropriate method of alignment, while the predictive ability was approved by a test set containing eight compounds with $\mathrm{r}_{\mathrm{ext}}{ }^{2}$ values of 0.990 and 0.987 , respectively. Moreover, the contour maps generated from CoMFA and CoMSIA models provided much helpful information to figure out the structural requirements that influence the activity. To further reinforce the 3D-QSAR results, the molecular docking method was implemented which led to the design of new potential insulin-independent antidiabetic compounds with high predicted activity values.
\end{abstract}

Keywords: 3D-QSAR, Molecular modeling, Computational study, Benzimidazole, a-amylase inhibitors.

Submitted: March 12, 2020. Accepted: May 10, 2020.

Cite this: El Khatabi K, Aanouz I, El-Mernissi R, Khaldan A, Ajana MA, Bouachrine M, et al. Design of Novel Benzimidazole Derivatives as Potential a-amylase Inhibitors by 3D-QSAR Modeling and Molecular Docking Studies. JOTCSA. $2020 ; 7(2): 471-80$.

DOI: https://doi.org/10.18596/jotcsa.703026.

*Corresponding author. E-mail: a.ajanamohammed@fs.umi.ac.ma.

\section{INTRODUCTION}

Diabetes mellitus (DM) is a chronic metabolic syndrome of multiple etiology characterized by hyperglycemia as its initial symptoms and glucose intolerance. The disease can be simply classified into insulin secretion (type 1 diabetes) or insulin action (type 2 diabetes) $(1,2)$. The digestive enzyme, a-Amylase, is the main form of amylase belonging to the family of glycoside hydrolases and found principally in pancreatic fluid and saliva. It is responsible for the biosynthesis of glycoproteins with an important role in the digestion of carbohydrate in the small intestine. Acute renal necrosis, cancer of urinary bladder, and active pyelonephritis are some urinary disorders and causes due to increasing the level of this enzyme(3). The glycoside hydrolases family can be isolated from many organisms including humans (4), animals $(5,6)$, plants $(7)$, and bacteria (8).

Benzimidazoles are a class of heterocyclic compounds that attracts much attention as promising bioactive molecules. Furthermore, benzimidazole is one of the privileged pharmacophores in drug discovery acting as a good ligand towards the transition metal ions using the nitrogen atom (9). This is due to their various reported anti-tumor (10), anti-fungal (11), antiinflammatory (12), antiviral (13), anti-ulcerative (14), and antimicrobial activities (15).

The structural parameters along with the application of the 3D-QSAR modeling and molecular docking 
methods have proved to be a promising avenue for structure-based drug design that can provide quantitative forecasts of activity and predict the activity of new organic compounds with a lowered economic investment costs (16). The current study aimed to explore the 3D-QSAR and molecular docking approaches (17) on a series of benzimidazole derivatives against a-amylase in order to develop a correlation between their inhibitory activities and structural characteristics. This would eventually facilitate the design and optimization of new potential a-amylase inhibitors with potent activities.

\section{MATERIALS AND METHODS}

\section{Dataset}

A set of forty-five compounds with their reported aamylase inhibition activities, IC $_{50}$ was obtained from the literature (18). And the corresponding $\mathrm{IC}_{50}$ values (uM) were converted into the $\mathrm{pIC}_{50}$ values (Table 1 ). The dataset was split into the training set (37 molecules) and test set ( 8 molecules). Both sets were selected at random to create the quantitative model.

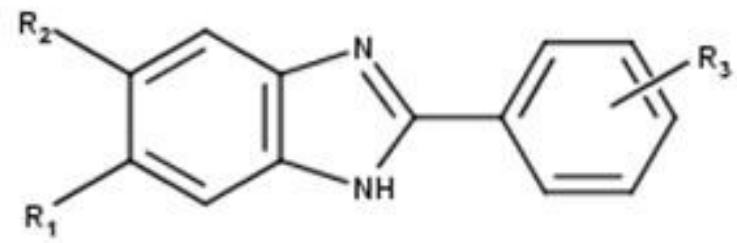

Figure 1. The structural template of the benzimidazole derivatives, 1-45.

Table 1. $\mathrm{IC}_{50}$ values of the reported 2-Aryl benzimidazole derivatives against a-amylase.

\begin{tabular}{|c|c|c|c|c|c|}
\hline $\begin{array}{c}\text { Training/ } \\
\text { Test }\end{array}$ & Comp. & $\mathbf{R}_{1}$ & $\mathbf{R}_{\mathbf{2}}$ & $\mathbf{R}_{\mathbf{3}}$ & pIC $_{50}$ \\
\hline Test & 1* & $\mathrm{H}$ & $\mathrm{H}$ & $2-\mathrm{Cl}-3-\mathrm{OCH}_{3}$ & 5.562 \\
\hline Test & 2* & $\mathrm{H}$ & $\mathrm{H}$ & $2-\mathrm{OH}-3-\mathrm{OCH}_{3}-6-\mathrm{Br}$ & 5.605 \\
\hline Training & 3 & $\mathrm{H}$ & $\mathrm{H}$ & 3,4-diOCH${ }_{3}-6-\mathrm{Br}$ & 5.821 \\
\hline Training & 4 & $\mathrm{H}$ & $\mathrm{H}$ & $2-\mathrm{OH}-3-\mathrm{Br}-5-\mathrm{Cl}$ & 5.555 \\
\hline Training & 5 & $\mathrm{CH}_{3}$ & $\mathrm{CH}_{3}$ & 3,6-diOH & 5.524 \\
\hline Training & 6 & $\mathrm{CH}_{3}$ & $\mathrm{CH}_{3}$ & $4-\mathrm{OCH}_{3}-6-\mathrm{F}$ & 5.555 \\
\hline Training & 7 & $\mathrm{CH}_{3}$ & $\mathrm{CH}_{3}$ & $5-\mathrm{OCH}_{3}-6-\mathrm{Cl}$ & 5.546 \\
\hline Training & 8 & $\mathrm{CH}_{3}$ & $\mathrm{CH}_{3}$ & 4,5,6-triOCH 3 & 5.638 \\
\hline Test & 9* & $\mathrm{CH}_{3}$ & $\mathrm{CH}_{3}$ & $2-\mathrm{OH}-3-\mathrm{OCH}_{3}-6-\mathrm{Br}$ & 5.585 \\
\hline Training & 10 & $\mathrm{CH}_{3}$ & $\mathrm{CH}_{3}$ & $3,4-\mathrm{diOCH}_{3}-6-\mathrm{Br}$ & 5.829 \\
\hline Training & 11 & $\mathrm{CH}_{3}$ & $\mathrm{CH}_{3}$ & $3,5-\mathrm{diOCH}_{3}-4-\mathrm{Br}$ & 5.790 \\
\hline Training & 12 & $\mathrm{CH}_{3}$ & $\mathrm{CH}_{3}$ & 3-I-4-OH-5-OCH 3 & 5.751 \\
\hline Training & 13 & $\mathrm{CH}_{3}$ & $\mathrm{CH}_{3}$ & $3-\mathrm{Cl}-5-\mathrm{Br}-6-\mathrm{OH}$ & 5.530 \\
\hline Training & 14 & $\mathrm{CH}_{3}$ & $\mathrm{CH}_{3}$ & $3,5-\mathrm{diCl}-6-\mathrm{OH}$ & 5.520 \\
\hline Training & 15 & $\mathrm{H}$ & $\mathrm{F}$ & $4,6-\mathrm{diOH}$ & 5.520 \\
\hline Training & 16 & $\mathrm{H}$ & $\mathrm{F}$ & $4-\mathrm{OCH}_{3}-6-\mathrm{F}$ & 5.790 \\
\hline Test & 17* & $\mathrm{H}$ & $\mathrm{F}$ & $2-\mathrm{OCH}_{3}-5-\mathrm{Br}$ & 5.585 \\
\hline Test & 18* & $\mathrm{H}$ & $\mathrm{F}$ & $5-\mathrm{OCH}_{3}-6-\mathrm{Cl}$ & 5.580 \\
\hline Training & 19 & $\mathrm{H}$ & $\mathrm{F}$ & $4-\mathrm{OAC}-5-\mathrm{OCH}_{3}$ & 5.770 \\
\hline Training & 20 & $\mathrm{H}$ & $\mathrm{F}$ & 4,5,6-triOH & 5.595 \\
\hline Training & 21 & $\mathrm{H}$ & $\mathrm{F}$ & $3,5-\mathrm{diOCH}_{3}-4-\mathrm{OH}$ & 5.603 \\
\hline Training & 22 & $\mathrm{H}$ & $\mathrm{F}$ & $2-\mathrm{OH}-3-\mathrm{OCH}_{3}-6-\mathrm{Br}$ & 5.663 \\
\hline Training & 23 & $\mathrm{H}$ & $\mathrm{F}$ & $3,4-\mathrm{diOCH}_{3}-6-\mathrm{Br}$ & 5.804 \\
\hline Training & 24 & $\mathrm{H}$ & $\mathrm{F}$ & $4,5-\mathrm{diOCH}_{3}-6-\mathrm{Cl}$ & 5.591 \\
\hline Training & 25 & $\mathrm{H}$ & $\mathrm{F}$ & $3,5-\mathrm{diCl}-6-\mathrm{OH}$ & 5.542 \\
\hline Training & 26 & $\mathrm{H}$ & $\mathrm{F}$ & $3-\mathrm{Cl}-5-\mathrm{Br}-6-\mathrm{OH}$ & 5.543 \\
\hline Training & 27 & $\mathrm{H}$ & $\mathrm{Cl}$ & $4-\mathrm{OAC}-5-\mathrm{OCH}_{3}$ & 5.774 \\
\hline Training & 28 & $\mathrm{H}$ & $\mathrm{Cl}$ & $5-\mathrm{OCH}_{3}-6-\mathrm{Cl}$ & 5.555 \\
\hline Training & 29 & $\mathrm{H}$ & $\mathrm{Cl}$ & $2-\mathrm{OCH}_{3}-5-\mathrm{Br}$ & 5.581 \\
\hline Test & $30 *$ & $\mathrm{H}$ & $\mathrm{Cl}$ & $4-\mathrm{OCH}_{3}-6-\mathrm{F}$ & 5.562 \\
\hline Training & 31 & $\mathrm{H}$ & $\mathrm{Cl}$ & $3,4-\mathrm{diOCH}_{3}-6-\mathrm{Br}$ & 5.761 \\
\hline Training & 32 & $\mathrm{H}$ & $\mathrm{Cl}$ & 3-I-4-OH-5-OCH 3 & 5.793 \\
\hline Test & 33* & $\mathrm{H}$ & $\mathrm{Cl}$ & $3-\mathrm{Cl}-5-\mathrm{Br}-6-\mathrm{OH}$ & 5.543 \\
\hline Training & 34 & $\mathrm{H}$ & $\mathrm{Cl}$ & $4,5-\mathrm{diOCH}_{3}-6-\mathrm{Cl}$ & 5.821 \\
\hline Training & 35 & $\mathrm{H}$ & $\mathrm{Cl}$ & $3,5-\mathrm{diOCH}_{3}-4-\mathrm{Br}$ & 5.790 \\
\hline Training & 36 & $\mathrm{H}$ & $\mathrm{Cl}$ & $2-\mathrm{Br}-5-\mathrm{OCH}_{3}-6-\mathrm{OH}$ & 5.655 \\
\hline Training & 37 & $\mathrm{H}$ & $\mathrm{Cl}$ & $3,5-\mathrm{diOCH}_{3}-4-\mathrm{OH}$ & 5.598 \\
\hline Training & 38 & $\mathrm{H}$ & $\mathrm{NO}_{2}$ & $4-\mathrm{OAC}-5-\mathrm{OCH}_{3}$ & 5.761 \\
\hline
\end{tabular}




\begin{tabular}{cccccc}
\hline $\begin{array}{c}\text { Training/ } \\
\text { Test }\end{array}$ & Comp. & $\mathbf{R}_{\mathbf{1}}$ & $\mathbf{R}_{\mathbf{2}}$ & $\mathbf{R}_{\mathbf{3}}$ & pIC \\
\hline Training & $\mathbf{3 9}$ & $\mathrm{H}$ & $\mathrm{NO}_{2}$ & $4-\mathrm{OCH}_{3}-6-\mathrm{F}$ & 5.560 \\
Training & $\mathbf{4 0}$ & $\mathrm{H}$ & $\mathrm{NO}_{2}$ & $5-\mathrm{OCH}_{3}-6-\mathrm{Cl}$ & 5.556 \\
Training & $\mathbf{4 1}$ & $\mathrm{H}$ & $\mathrm{NO}_{2}$ & $2-\mathrm{Br}^{2}-\mathrm{OCH}_{3}-6-\mathrm{OH}$ & 5.640 \\
Training & $\mathbf{4 2}$ & $\mathrm{H}$ & $\mathrm{NO}_{2}$ & $3,4-\mathrm{diOCH}_{3}-6-\mathrm{Br}$ & 5.749 \\
Training & $\mathbf{4 3}$ & $\mathrm{H}$ & $\mathrm{NO}_{2}$ & $3-\mathrm{I}-4-\mathrm{OH}-5-\mathrm{OCH}$ & 5.764 \\
Training & $\mathbf{4 4}$ & $\mathrm{H}$ & $\mathrm{NO}_{2}$ & $3-\mathrm{Cl}-5-\mathrm{Br}-6-\mathrm{OH}$ & 5.542 \\
Test & $\mathbf{4 5 *}$ & $\mathrm{H}$ & $\mathrm{NO}_{2}$ & $2-\mathrm{F}-5-\mathrm{Br}$ & 5.634 \\
\hline
\end{tabular}

\section{Molecular modeling}

The studied molecules were constructed and minimized using the SKETCH option in SYBYL-X 2.0 program package (19) running on a windows 10, 64 bit workstation/ASUS, under the Tripos standard force field (20) with Gasteiger-Hückel atomic partial charges (21) by the Powell method with a convergence criterion of $0.01 \mathrm{kcal} / \mathrm{mol} \AA$. Sybyl program provides a molecular design environment to identify, predict and analyze molecular behavior.

\section{Molecular alignment}

Molecular alignment aims to build an efficiency of the 3D-QSAR models. The studied molecules were stratified on the common core; 2-aryl benzimidazole using the simple alignment protocol in Sybyl (22). Compound $\mathbf{1 0}$ was selected as a representative template for superimposing structures as shown in Figure 2.

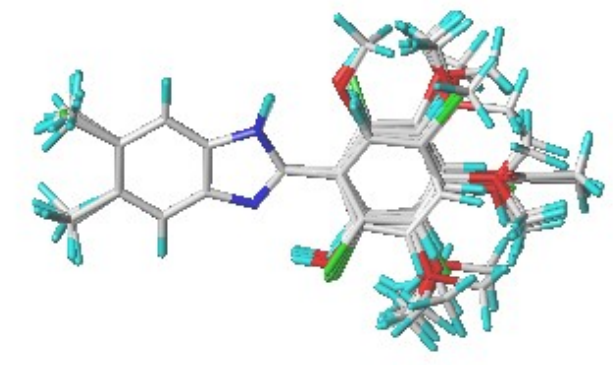

Aligned compounds

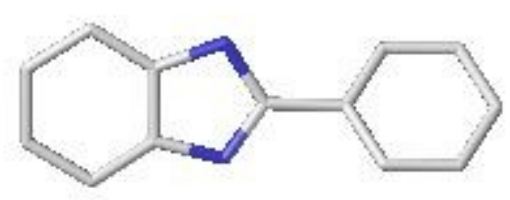

common core

Figure 2. 3D-QSAR aligned molecules using compound 10 as a template.

\section{D QSAR analyses}

On the basis of molecular alignment protocol which is considered as one of the most crucial factors that affects the accuracy of 3D-QSAR models, comparative molecular field analysis (CoMFA) (23) and comparative molecular similarity indices analysis (CoMSIA) (24) models were developed to derive a linear relationship between the obtained QSAR models and a-amylase enzyme inhibitory activities. 3D-QSAR study was performed with the default parameters; the minimum sigma (column filtering) is set to $2.0 \mathrm{kcal} / \mathrm{mol}$ and the energy cutoff values of $30 \mathrm{kcal} / \mathrm{mol}(25)$.

The partial least squares (PLS) regression method was adopted to derive 3D-QSAR models (26). Hence the PLS with leave-one-out cross-validation was implemented to produce the coefficient of crossvalidation correlation $\left(\mathrm{Q}^{2}\right)$ with an optimum number of components $(\mathrm{N})$. And the non-cross validation was carried out to get the correlation coefficient $\left(R^{2}\right)$, F-test value $(F)$ and the standard error of estimate (SEE). Consequently, the best QSAR model is selected based on the high $Q^{2}$ value $\left(Q^{2}>0.50\right)$ and $R^{2}$ value $\left(R^{2}>0.60\right)$, an optimal number of component values, and low standard error estimation (SEE). Furthermore, the external validation was performed to evaluate the sturdiness of the generated 3D-QSAR models using eight molecules as a test set. Where the best value of $r_{\text {ext }}{ }^{2}$ $>0.6$ indicated that the predictive power of derived QSAR model was good (27).

\section{Molecular Docking}

The docking was carried out to further explore the binding interactions of the molecules in the active site of the a-amylase enzyme and confirm the contour maps results of CoMFA as well as the CoMSIA using the Surflex-Docking method (19). Further, the results were analyzed using PyMol (28) and Discovery studio 2016 softwares (29). The crystal structure of the a-amylase enzyme (PDB code: $1 \mathrm{HNY}$ ) with the co-crystallized ligand removed was utilized for this study. Using the Discovery Studio 2016, the protein was prepared by the addition of polar hydrogens and Kohlman charges while removing water molecules from the $1 \mathrm{HNY}$ receptor. The 3D structure of the representative compound $\mathbf{1 0}$ was geometrically optimized and energetically minimized using default parameters and consequently docked into the active site of the a-amylase enzyme. 


\section{Y-Randomization test}

The Y-Randomization test was performed to value the vigor of both models (30), and the inhibition activities $\left(-\log I C_{50}\right)$ were shuffled many times. A new 3D-QSAR model was is generated for each iteration. Besides, the low $\mathrm{Q}^{2}$ and $\mathrm{R}^{2}$ values pointed out that the results were not due to a chance correlation.

\section{RESULTS AND DISCUSSION}

\section{D-QSAR}

Based on the 3D-QSAR modeling, it appeared that the models might play substantial roles in predicting new potent insulin-independent antidiabetic agents as contained in the summary of PLS analyses (Table 2). Obviously, for the CoMFA model, the coefficient of cross-validated, $\mathrm{Q}^{2}$ value was 0.696 with 2 as the optimized component, $\mathrm{N}$. While the $\mathrm{R}^{2}$, SEE and F- test values were $0.860,0.041$ and 104.72, respectively. It thus implied that the high $\mathrm{Q}^{2}, \mathrm{R}^{2}$ and $F$ values along with low SEE value, suggest a good statistical correlation and reasonable predictive capability of the obtained models. Furthermore, the high $r_{\text {ext }}^{2}(0.990)$ value of the external validation exhibits a high level of reliability in the current study. Similarly, the ratio of steric to electrostatic contributions were set at 51:49, which means that both fields are much explanatory.

The most accurate CoMSIA model which involved the steric, electrostatic, hydrophobic, H-bond acceptor and donor fields showed $\mathrm{Q}^{2,} \mathrm{~N}, \mathrm{R}^{2}$, SEE, and $F$ values of $0.514,3,0.852,0.042 \quad 119.904$ respectively. The $\mathrm{r}_{\mathrm{ext}}{ }^{2}$ value obtained was 0.987 which approved the prediction ability of the obtained model. The experimental and predicted pIC50 are shown in Table 3.

Table 2. PLS statistical parameters.

\begin{tabular}{|c|c|c|c|c|c|c|c|c|c|c|c|}
\hline \multirow[t]{2}{*}{ Model } & \multirow[t]{2}{*}{$\mathbf{Q}^{2}$} & \multirow[t]{2}{*}{$\mathbf{R}^{2}$} & \multirow[t]{2}{*}{ SEE } & \multirow[t]{2}{*}{$\mathbf{F}$} & \multirow[t]{2}{*}{$\mathbf{N}$} & \multirow[t]{2}{*}{$r_{\text {ext }}^{2}$} & \multicolumn{5}{|c|}{ Fractions } \\
\hline & & & & & & & Ster & Elect & Hyd & Acc & Don \\
\hline $\begin{array}{c}\text { CoMFA } \\
\text { CoMSIA }\end{array}$ & $\begin{array}{l}0.696 \\
0.514\end{array}$ & $\begin{array}{l}0.860 \\
0.852\end{array}$ & $\begin{array}{l}0.041 \\
0.042\end{array}$ & $\begin{array}{c}104.72 \\
63.55\end{array}$ & $\begin{array}{l}2 \\
3\end{array}$ & $\begin{array}{l}0.990 \\
0.987\end{array}$ & $\begin{array}{l}0.514 \\
0.084\end{array}$ & $\begin{array}{l}0.486 \\
0.471\end{array}$ & $\begin{array}{c}- \\
0.229\end{array}$ & 0.138 & $\begin{array}{c}- \\
0.077\end{array}$ \\
\hline
\end{tabular}

Table 3. Experimental and predicted $\mathrm{pIC}_{50}$ of forty-five benzimidazole derivatives ( $*$ :test set )

\begin{tabular}{|c|c|c|c|c|c|c|c|}
\hline \multirow[t]{2}{*}{ Comp. } & \multirow{2}{*}{$\begin{array}{l}\text { Experimental } \\
\text { pIC }_{50}\end{array}$} & \multicolumn{2}{|c|}{ predicted pIC $_{50}$} & \multirow[t]{2}{*}{ Comp. } & \multirow{2}{*}{$\begin{array}{c}\text { Experimental } \\
\text { pIC }_{50}\end{array}$} & \multicolumn{2}{|c|}{ predicted pIC $_{50}$} \\
\hline & & CoMfA & CoMSIA & & & CoMFA & CoMSIA \\
\hline $1 *$ & 5.562 & 5.559 & 5.558 & 22 & 5.663 & 5.663 & 5.653 \\
\hline $2 *$ & 5.605 & 5.647 & 5.645 & 23 & 5.804 & 5.846 & 5.847 \\
\hline 3 & 5.821 & 5.861 & 5.858 & 24 & 5.591 & 5.655 & 5.658 \\
\hline 4 & 5.555 & 5.563 & 5.562 & 25 & 5.542 & 5.574 & 5.574 \\
\hline 5 & 5.524 & 5.493 & 5.493 & 26 & 5.543 & 5.578 & 5.578 \\
\hline 6 & 5.555 & 5.634 & 5.630 & 27 & 5.774 & 5.751 & 5.752 \\
\hline 7 & 5.546 & 5.541 & 5.542 & 28 & 5.555 & 5.588 & 5.587 \\
\hline 8 & 5.638 & 5.664 & 5.659 & 29 & 5.581 & 5.553 & 5.549 \\
\hline 9* & 5.585 & 5.568 & 5.601 & $30 *$ & 5.562 & 5.557 & 5.557 \\
\hline 10 & 5.829 & 5.817 & 5.816 & 31 & 5.761 & 5.755 & 5.758 \\
\hline 11 & 5.790 & 5.755 & 5.756 & 32 & 5.793 & 5.760 & 5.760 \\
\hline 12 & 5.751 & 5.714 & 5.713 & $33 *$ & 5.543 & 5.586 & 5.586 \\
\hline 13 & 5.530 & 5.523 & 5.525 & 34 & 5.821 & 5.721 & 5.716 \\
\hline 14 & 5.520 & 5.521 & 5.521 & 35 & 5.790 & 5.738 & 5.740 \\
\hline 15 & 5.520 & 5.518 & 5.521 & 36 & 5.655 & 5.663 & 5.658 \\
\hline 16 & 5.790 & 5.685 & 5.684 & 37 & 5.598 & 5.693 & 5.695 \\
\hline $17 *$ & 5.585 & 5.544 & 5.541 & 38 & 5.761 & 5.736 & 5.739 \\
\hline $18 *$ & 5.580 & 5.578 & 5.570 & 39 & 5.560 & 5.655 & 5.6657 \\
\hline 19 & 5.770 & 5.749 & 5.750 & 40 & 5.556 & 5.556 & 5.557 \\
\hline 20 & 5.595 & 5.513 & 5.517 & 41 & 5.640 & 5.56 & 5.655 \\
\hline \multirow[t]{4}{*}{21} & 5.603 & 5.688 & 5.686 & 42 & 5.749 & 5.715 & 5.720 \\
\hline & & & & 43 & 5.764 & 5.726 & 5.727 \\
\hline & & & & 44 & 5.542 & 5.493 & 5.557 \\
\hline & & & & $45 *$ & 5.634 & 5.616 & 5.617 \\
\hline
\end{tabular}




\section{Interpretation of graphical contours}

The graphical contour maps were created to visualize areas where the activity can be increased or decreased. Figures 3 and 4 show the CoMFA and CoMSIA contour maps respectively for compound $\mathbf{1 0}$ as a representative molecule.

\section{CoMfA contour maps}

The electrostatic fields are presented with red $(20 \%$ contribution) and blue ( $80 \%$ contribution) contours, while the steric fields are presented with green ( $80 \%$ contribution) and yellow ( $20 \%$ contribution) contours. The bulky substituents are preferred around green areas, whereas yellow areas' bulky substituents are not preferred (Figure 3).

As depicted in Figure 3, a relatively big yellow contour was observed around the phenyl group which could be favored to activity while the smallsized green contour around the $\mathrm{C}-3$ position indicated that less bulky group at this position would

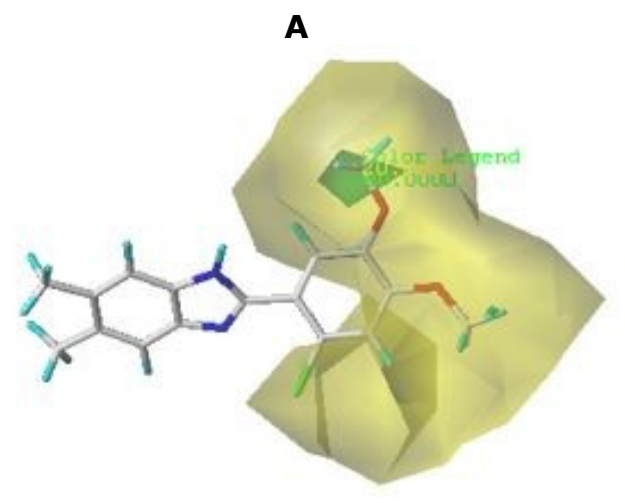

not be favorable for increasing the activity, which could be demonstrated by compounds 4, 13, 14, 25, 26, 33 and 44. For example, the compounds $13\left(\mathrm{pIC}_{50}=5.530\right)$ and $14\left(\mathrm{pIC}_{50}=5.520\right)$, with halogens at the 3 and 5 positions of the phenyl moiety, showed low activities than that of compound 10 ( $\mathrm{pIC}_{50}=5.829$ ), with $\mathrm{OCH}_{3}$ and $\mathrm{H}$ groups at the same positions, respectively.

Moreover, figure 3 revealed that that phenyl group with the electropositive substituents may increase the activity around the blue contours. As such three major space-favorable blue regions were distributed around the ortho, meta and para positions of the phenyl ring. This indicated that the existence of these electron donor groups at these positions could increase the activity. Therefore, electropositive and less bulky groups are required at these positions which could easily reach the binding pocket in the enzyme active sites and present high a-amylase inhibition affinity.



Figure 3. Analysis of CoMFA contour maps. (A) Steric field; (B) Electrostatic field.

\section{CoMSIA contour map}

The CoMSIA contour maps for the steric and electrostatic fields were found to be similar to the corresponding CoMFA fields. Therefore, the focus was directed towards the remaining parameters. Hence according to the CoMSIA fractions presented in Table 2, the electrostatic (0.471); H-bond acceptor (0.138); and hydrophobic fields (0.229) were found to be the major fields that could describe the activity.

The contour map for the hydrophobic field (Figure $4(\mathrm{a}))$ is depicted in yellow domains $(80 \%$ contribution) and white domains ( $20 \%$ contribution) in which hydrophobic substituents are predicted to enhance the biological activity in yellow contours, whereas in white domain, hydrophobic groups were not favored. The yellow contour near the ortho position of the phenyl group brought to light that the hydrophobicity could play a crucial role in the activity. For example, compound $\mathbf{2 3}\left(\mathrm{pIC}_{50}=5.804\right.$ ) with a $-\mathrm{Br}$ group at the $\mathrm{C}-2$, which is falls within the yellow contours, exhibited higher activity than those with no hydrophilic groups such as; compounds $\mathbf{1 5}$ $\left(p C_{50}=5.520\right)$ and $26\left(p C_{50}=5.542\right)$, which lead into increase of activity. Moreover, two white contours near the $\mathrm{C}-3$ and $\mathrm{C}-5$ positions of the phenyl group pointed that the presence of a hydrophobic group especially halogens in this region may not be beneficial to the biological activity. For instance, compounds $4\left(\mathrm{pIC}_{50}=5.555\right)$ and 33 $\left(p C_{50}=5.543\right)$ with halogens groups at C-3 and C5 position of the phenyl moiety exhibit lowest activities than that of the corresponding compound $10\left(\mathrm{pIC}_{50}=5.829\right)$.

The CoMSIA hydrogen bond acceptor field (Figure $4(\mathrm{~b}))$, is displayed in magenta ( $80 \%$ contribution) and red ( $20 \%$ contribution) contours, representing favorable and unfavorable positions for $\mathrm{H}$-bond acceptors respectively. A relatively big red contour was observed around C-2, C-3 and C-4 positions of the phenyl group which has been proven to be a disadvantage to activity due to the existence of $\mathrm{H}$ - 
bond acceptor substituent at one or two of these positions. Whereas, the magenta contour around the C-5 position of the phenyl moiety is crucial for significant inhibitory activity. These characteristics may explain significant a-amylase inhibitory activity for compounds with no hydrogen bond acceptor groups such as; compound $\mathbf{1 1}$ and compound 10, respectively. For instance, compound $\mathbf{1 1}\left(\mathrm{pIC}_{50}=\right.$ 5.790) without any substituent and compound $\mathbf{1 0}$ $\left(\mathrm{pIC}_{50}=5.829\right)$ with a $-\mathrm{Br}$ showed high activities.

\section{Y-randomization test}

Table 4 shows the results of seven random shuffles for the $\mathrm{Y}$-randomization test. For every iteration, a set of $\mathrm{Q}^{2}$ and $\mathrm{R}^{2}$ of new QSAR models is generated.
In the contour map of $\mathrm{H}$-bond donor field, as shown in Figure $4(\mathrm{c})$, the cyan ( $80 \%$ contribution) and the purple ( $20 \%$ contribution) contours represent areas with favorable and unfavorable $\mathrm{H}$-bond donor groups respectively. A big-sized cyan contour is found around the phenyl ring, indicating that $\mathrm{H}$ bond donor substituents in this area are predicted to enhance biological activity.

As a result, the $\mathrm{Q}^{2}$ and $\mathrm{R}^{2}$ values were low. Thus allowing to conclude that the probability of random correlations was excluded.

Table 4. $\mathrm{Q}^{2}$ and $\mathrm{R}^{2}$ values of the $\mathrm{Y}$-randomization test.

\begin{tabular}{ccccc}
\hline Iteration & \multicolumn{2}{c}{ CoMFA } & \multicolumn{2}{c}{ CoMSIA } \\
& $\mathbf{Q}^{\mathbf{2}}$ & $\mathbf{R}^{\mathbf{2}}$ & $\mathbf{Q}^{\mathbf{2}}$ & $\mathbf{R}^{\mathbf{2}}$ \\
\hline $\mathbf{1}$ & 0.082 & 0.128 & 0.048 & 0.134 \\
$\mathbf{2}$ & 0.125 & 0.317 & 0.121 & 0.242 \\
$\mathbf{3}$ & 0.199 & 0.421 & 0.178 & 0.391 \\
$\mathbf{4}$ & 0.167 & 0.360 & 0.142 & 0.308 \\
$\mathbf{5}$ & -0.214 & 0.248 & -0.199 & 0.195 \\
$\mathbf{6}$ & 0.099 & 0.126 & 0.092 & 0.102 \\
$\mathbf{7}$ & 0.137 & 0.301 & 0.129 & 0.284 \\
\hline
\end{tabular}

\section{Molecular docking}

To reinforce the 3D-QSAR results, the molecular docking technique was applied to investigate the different interactions of benzimidazole derivatives in the active site of a-amylase (PDB code: $1 \mathrm{HNY}$ ) using the Surflex program. The potent compounds were found to be those that contain ortho $\mathrm{Cl}$ or $\mathrm{Br}$ atom, para and meta methoxy groups on the phenyl ring which could be responsible for these compounds' inhibitory activity. As depicted in Figure 5, the representative compound $\mathbf{1 0}$ which is originally reported to be the most effective compound was docked in the a-amylase enzyme active site. This enabled the understanding of the hydrophobic and
$\mathrm{H}$-bond interactions between the active molecule and $1 \mathrm{HNY}$ receptor.

The blue and pink colors around C-2, C-3 and C-4 positions of the phenyl ring indicated that substituents with hydrophilic character and $\mathrm{H}$-bond donor substituents are favored in these positions. The R1 and R2 substituents were found in the brown area which implied that the groups with the hydrophobic characters at these positons would be favored. The observations obtained from the hydrophobicity and $\mathrm{H}$-bond surfaces are in agreement with the contour maps of CoMSIA model. 
A

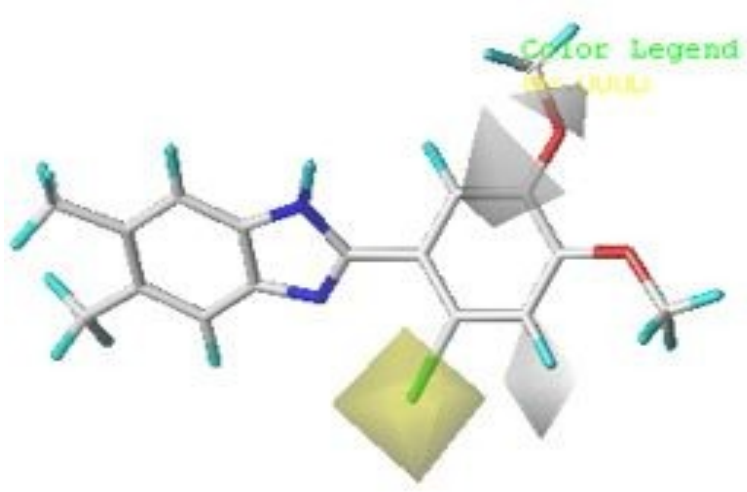

C

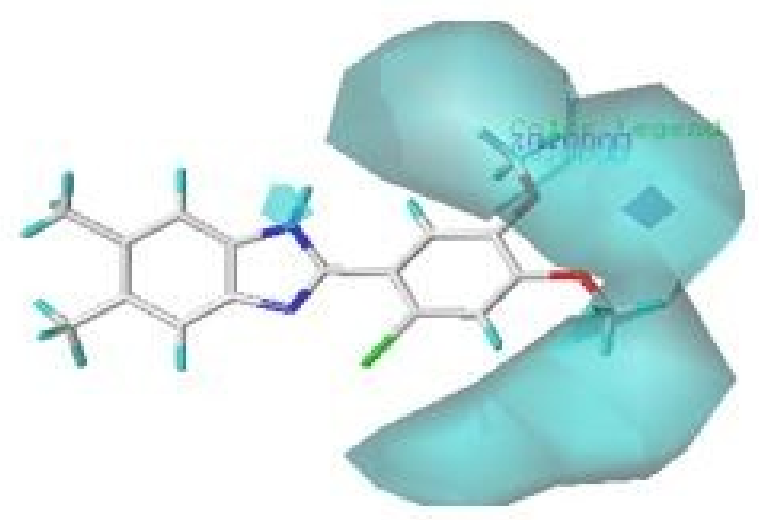

B

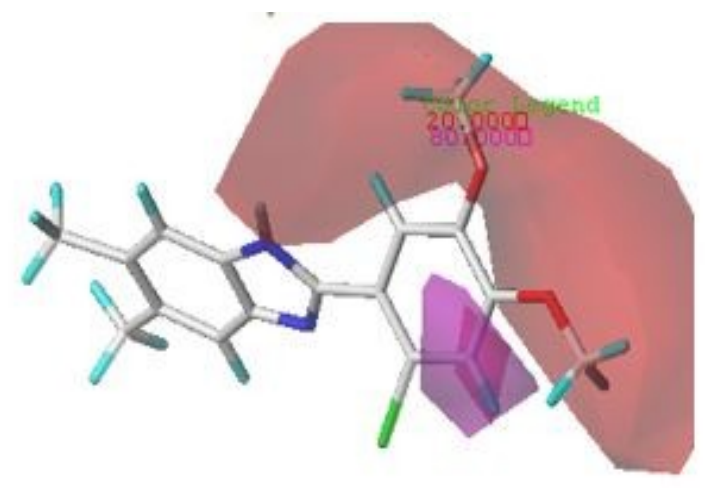

Figure 4. Analysis of CoMSIA contour maps. (A) Hydrophobic field; (B) H-bond acceptor field; (C) H-bond donor field

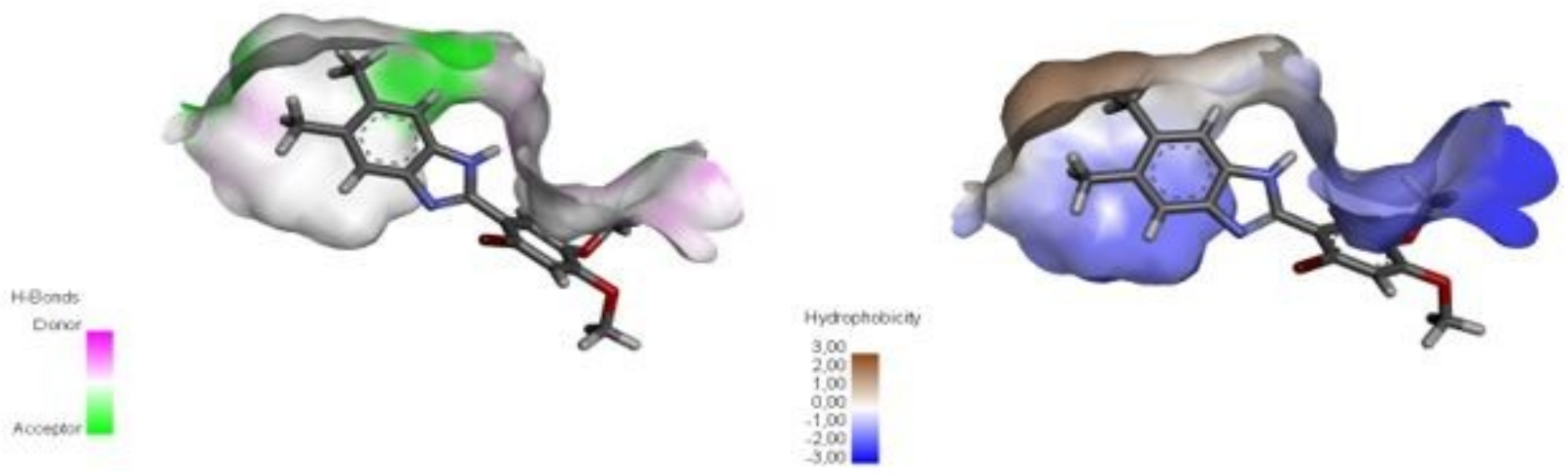

Figure 5. The docking pose of the active molecule and 1 HNY receptor. 


\section{SAR summarized results}

Figure 6 summarized the information derived from the 3D contour maps that satisfactorily matched the results of molecular docking, which could be much helpful to propose new molecules with high predictive activities.

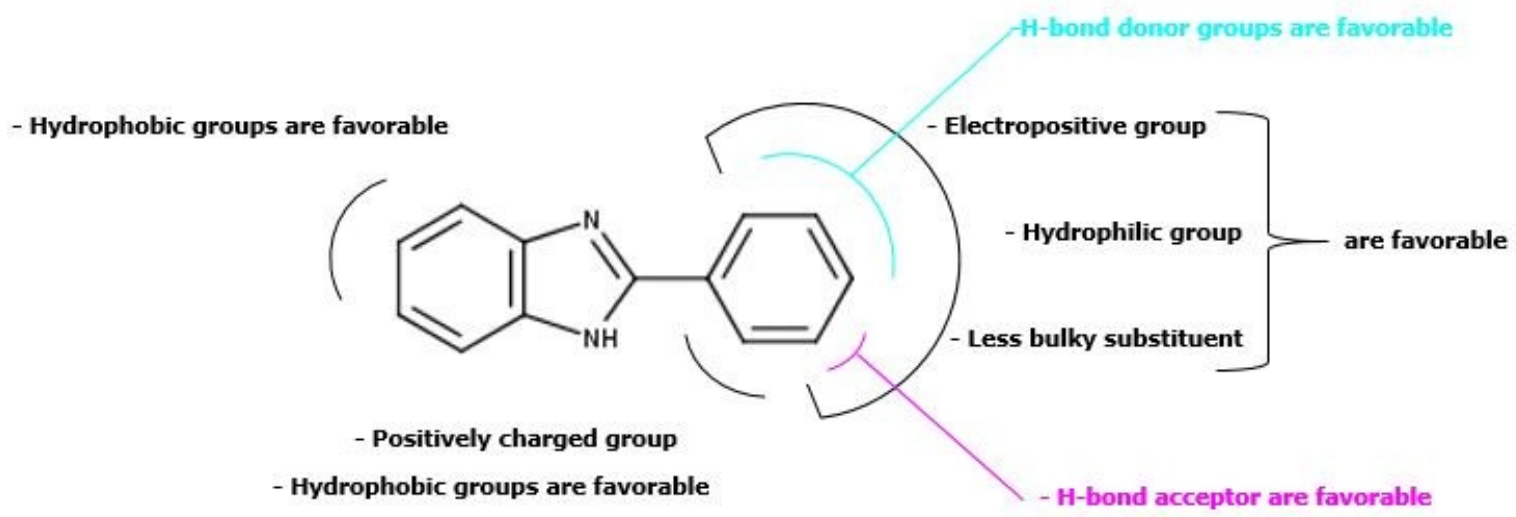

Figure 6. SAR-summarized results from the present work.

\section{Newly designed compounds}

Based on the information obtained from the 3D contour maps and molecular docking studies, five new 2-aryl-benzimidazole derivatives which exhibited high $\mathrm{pIC}_{50}$ values were designed. The newly predicted compounds $A 1, A 2, A 3, A 4$ and $A 5$ showed exceptionally improved inhibitory activity and higher total score (binding affinities) than that of compound 10 for both models, indicating their potential as new a-amylase inhibitors as shown in Table 5.



Figure 7. The structural template of the newly designed molecules.

Table 5. The $\mathrm{pIC}_{50}$ values of newly designed 2-arylbenzimidazole derivatives as a-amylase inhibitors.

\begin{tabular}{ccccc}
\hline No & R & \multicolumn{2}{c}{ Predicted pIC50 } & Total \\
& & CoMFA & CoMSIA & scoring \\
\hline Comp 10 & 3,4-diOCH $-6-\mathrm{Br}$ & 5.817 & 5.816 & 1.7149 \\
A1 & 2-OH-3- $-\mathrm{NHCH}_{3}$ & 6.353 & 6.340 & 3.2841 \\
A2 & $2-\mathrm{NH}_{2}-3-\mathrm{OH}$ & 6.326 & 6.325 & 3.2719 \\
A3 & $2,3,6-\mathrm{triOH}$ & 6.299 & 6.297 & 3.2722 \\
A4 & 2-OH-3- $\mathrm{NH}_{2}$ & 6.092 & 6.101 & 2.9940 \\
A5 & 2,4,6-triNH & 6.052 & 6.076 & 2.9866 \\
\hline
\end{tabular}

\section{CONCLUSION}

The current study has provided some valuable information on the design of new potential insulinindependent antidiabetic agents. This has been achieved through investigating forty-five benzimidazole derivatives retrieved from the literature by molecular docking and 3D-QSAR studies. Graphical analyses of the optimal results obtained from the contour maps brought to light the main structural requirements that may influence the activity. Moreover, the molecular docking analyses matched well with the results obtained from the contour maps which led to the design of five potent insulin-independent antidiabetic molecules and successfully predicted their a-amylase inhibitory activities. 


\section{ACKNOWLEDGEMENTS}

We are grateful to the "Association Marocaine des Chimistes Théoriciens" (AMCT) for its pertinent help concerning the software programs.

\section{REFERENCES}

1. Orbak R, Simsek S, Orbak Z, Kavrut F, Colak M. The Influence of Type-1 Diabetes Mellitus on Dentition and Oral Health in Children and Adolescents. Yonsei Med J. 2008;49(3):357-365.

2. Latti BR, Kalburge JV, Birajdar SB, Latti RG. Evaluation of relationship between dental caries, diabetes mellitus and oral microbiota in diabetics. J Oral Maxillofac Pathol JOMFP. 2018;22(2):282.

3. Gonick HC, Kramer HJ, Schapiro AE. Urinary BGlucuronidase Activity in Renal Disease. Arch Intern Med. 1973;132(1):63-69.

4. Kim D-H, Lee S-W, Han MJ. Biotransformation of Glycyrrhizin to $18 \beta$-Glycyrrhetinic Acid-3-O- $\beta$-Dglucuronide by Streptococcus LJ-22, a Human Intestinal Bacterium. Biol Pharm Bull. 1999;22(3):320-322.

5. Abou-Haila A, Orgebin-Crist M-C, Skudlarek MD, Tulsiani DRP. Identification and androgen regulation of egasyn in the mouse epididymis. Biochim Biophys Acta BBA - Mol Cell Res. 1998;1401(2):177-186.

6. Pereira W, Cruz A, Albuquerque E, Santos E, Oliveira $A$, Sales $M$, et al. Purification and Characterization of a $B$ Glucuronidase Present During Embryogenesis of the Mollusk Pomacea sp. Protein Pept Lett. 2005;12(7):695-700.

7. Zhang $C$, Zhang $Y$, Chen J, Liang $X$. Purification and characterization of baicalin- $\beta$-d-glucuronidase hydrolyzing baicalin to baicalein from fresh roots of Scutellaria viscidula Bge. Process Biochem. 2005;40(5):1911-1915.

8. Wang $X$, Liu Y, Wang C, Feng $X$, Li C. Properties and structures of $\beta$-glucuronidases with different transformation types of glycyrrhizin. RSC Adv. 2015;5(84):68345-68350.

9. Küçükbay H. PART I: MICROWAVE-ASSISTED SYNTHESIS OF BENZIMIDAZOLES: AN OVERVIEW (UNTIL 2013). J Turk Chem Soc Sect Chem 2017; 4(1):1-22.

10. Küçükbay $H$, Mumcu A, Tekin S, Sandal S. Synthesis and evaluation of novel $N$, $N^{\prime}$-disubstituted benzimidazolium bromides salts as antitumor agents. Turk J Chem. 2016;40(3):393-401.

11. Khabnadideh S, Rezaei Z, Pakshir K, Zomorodian K, Ghafari N. Synthesis and antifungal activity of benzimidazole, benzotriazole and aminothiazole derivatives. $2012 ; 7(2): 65-72$.

12. Sondhi SM, Singh N, Kumar A, Lozach O, Meijer L. Synthesis, anti-inflammatory, analgesic and kinase (CDK1, CDK-5 and GSK-3) inhibition activity evaluation of benzimidazole/benzoxazole derivatives and some Schiff's bases. Bioorg Med Chem. 2006;14(11):3758-65.
13. Salahuddin, Shaharyar M, Mazumder A. Benzimidazoles: A biologically active compounds. Arab J Chem. 2017;10:157-73.

14. Carcanague D, Shue $\mathrm{Y}-\mathrm{K}$, Wuonola MA, UriaNickelsen $M$, Joubran C, Abedi JK, et al. Novel Structures Derived from 2-[[(2-Pyridyl)methyl]thio ]-1 $H$ benzimidazole as Anti- Helicobacter $p$ ylori Agents, Part 2. J Med Chem. 2002;45(19):4300-9.

15. Küçükbay $H$, Yilmaz Ü, Şireci $N$, Güvenç AN. Synthesis and antimicrobial activities of some bridged bisbenzimidazole derivatives. Turk J Chem. 2011;35(4):561-71.

16. Ou-Yang S, Lu J, Kong $X$, Liang $Z$, Luo C, Jiang $H$. Computational drug discovery. Acta Pharmacol Sin. 2012;33(9):1131-40.

17. Understanding the Basics of QSAR for Applications in Pharmaceutical Sciences and Risk Assessment 1, Kunal Roy, Supratik Kar, Rudra Narayan Das - Amazon.com [Internet]. available on: https://www.amazon.com/Understanding-ApplicationsPharmaceutical-Sciences-Assessment-ebook/dp/ B00URFMD7Q

18. Adegboye AA, Khan KM, Salar U, Aboaba SA, Kanwal, Chigurupati $S$, et al. 2-Aryl benzimidazoles: Synthesis, In vitro a-amylase inhibitory activity, and molecular docking study. Eur J Med Chem. 2018; $150: 248-60$.

19. Sybyl-X [Internet]. omicX. available on: https://omictools.com/sybyl-x-tool

20. Clark M, Cramer RD, Van Opdenbosch N. Validation of the general purpose tripos 5.2 force field. J Comput Chem. 1989;10(8): 982-1012.

21. Purcell WP, Singer JA. A brief review and table of semiempirical parameters used in the Hueckel molecular orbital method. J Chem Eng Data. 1967;12(2):235-46.

22. SCIGRESS - a unique desktop molecular modeling software package [Internet]. available on:https://fqs.pl/en/chemistry/products/scigress? gclid=EAIaIQobChMIsrORqqe95wIVw7HtChObGAueEAAYAS AAEgJOM_D_BwE

23. Cramer RD, Patterson DE, Bunce JD. Comparative molecular field analysis (CoMFA). 1. Effect of shape on binding of steroids to carrier proteins. J Am Chem Soc. $1988 ; 110(18)$ :5959-67.

24. Klebe G, Abraham $U$, Mietzner T. Molecular Similarity Indices in a Comparative Analysis (CoMSIA) of Drug Molecules to Correlate and Predict Their Biological Activity. J Med Chem. 1994;37(24):4130-46.

25. Ståhle L, Wold S. 6 Multivariate Data Analysis and Experimental Design in Biomedical Research. In: Progress in Medicinal Chemistry [Internet]. Elsevier; 1988:291-338. available

on: https://linkinghub.elsevier.com/retrieve/pii/S00796468087 02819

26. Bush BL, Nachbar RB. Sample-distance partial least squares: PLS optimized for many variables, with application to CoMFA. J Comput Aided Mol Des. $1993 ; 7(5): 587-619$. 
27. Baroni M, Clementi S, Cruciani G, Costantino G, Riganelli $D$, Oberrauch E. Predictive ability of regression models. Part II: Selection of the best predictive PLS model. J Chemom. 1992;6(6):347-56.

28. DeLano WL. Pymol: An open-source molecular graphics tool. CCP4 Newsl Protein Crystallogr. 2002;40(1):82-92.
29. Discovery Studio Predictive Science Application | Dassault Systèmes BIOVIA [Internet]. available on: https://www.3dsbiovia.com/products/collaborativescience/biovia-discovery-studio/

30. Rücker C, Rücker G, Meringer M. y-Randomization and Its Variants in QSPR/QSAR. J Chem Inf Model. 2007;47(6):2345-57. 